\title{
Performance Evaluation of Woven Polyethylene Formwork on Tie Beam and Pile Cap Structure in Terms of Cost and Time
}

\author{
Novena Ulimandalany Barus, Jessica Sjah", Ayomi Dita Rarasati \\ Department of Civil Engineering, Faculty of Engineering, Universitas Indonesia, Depok, West Java, Indonesia
}

Received February 25, 2020; Revised May 19, 2020; Accepted May 27, 2020

Copyright $(2020$ by authors, all rights reserved. Authors agree that this article remains permanently open access under the terms of the Creative Commons Attribution License 4.0 International License

\begin{abstract}
One of the most important components in the construction execution is concrete works. Therefore, we need formworks to form the structural elements that are planned in a construction process. In the process, an economical alternative needs to be taken regarding choosing formwork material to get more benefits, both in terms of cost and time. Fabric formwork can be an alternative solution for formwork material. An example of a feasible formwork material alternative is woven polyethylene-based formwork. The purpose of this research is to evaluate the performance value of woven polyethylene formwork and compare it with the conventional formworks such as wood and brick in terms of cost and time. Field observations and literature reviews have been done to answer these questions. By using woven polyethylene formwork on tie beam and pile cap structure, it was found that the average time and the investment cost of installation are consecutively $344.23 \mathrm{~s} / \mathrm{m}^{2}$ and IDR75000 which is faster and cheaper than using conventional ones.
\end{abstract}

Keywords Fabric Formwork, Woven Polyethylene, Concrete Structure, Construction, Performance Evaluation

\section{Introduction}

Concrete work is one of the most important components of the construction project. Concrete is a material that can reduce building maintenance costs, give the fire resistance to the building, is able to reduce noise, so it can provide a longer life to a building (Hanna, 1999). Therefore, concrete needs a mould to form the structural elements in the construction projects, which is usually called formwork. Formwork is defined as a temporary structure whose purpose is to provide support and resistance until the concrete can support its own weight. In terms of cost, formwork contributes $40-60 \%$ of total concrete work and about $10 \%$ of total building costs (Hanna, 1999). Based on this research, the construction team should make an economical decision from the material selection to the formwork installation, so it can provide a benefit both in terms of cost and time (Jones, 2003; Umit Dikmen \& Sonmez, 2011).

Along with the times, there is a new type of formwork called fabric formwork (Hurd, 1995; Veenendaal \& Block, 2012; West \& Araya, 2012; Chandler, 2015; Hawkins et al., 2016; West, 2016). Fabric formwork has actually begun to be used in concrete construction since the early 1900s. In the 1960s, this formwork started to widely be used, triggered by the availability of high-strength and low-cost fabric materials (Lamberton, 1989). At this time, fabric formwork was used as a concrete mould for foundation, underwater and other concrete works (West, 1994; Van Mele \& Block, 2011 ; Orr et al., 2011; Seracino et al, 2012; Veenendaal \& Block, 2014; Pedreschi \& Lee, 2015). The interest of fabric formwork is coming from an architect named Miguel Fisac, who has a patent about the construction method for prefabricated fabric wall panels (Orr et al., 2011). Since then, various design and construction methods for fabric formwork have been developed, including the zero waste system, to the recording of significant savings in material and labour costs due to the use of fabric formwork (Sutherland, 2005; Chang, 2007).

The use of fabric formwork can save up to $40 \%$ of the use of concrete compared to the use of other formwork materials. In addition, the use of fabric formwork also gives a better concrete surface finish compared to other formwork materials. This will reduce the maintenance and repair of printed fabric formwork (Orr et al., 2011). Nevertheless, the use of fabric formwork in Indonesia is 
still minim when compared to other types of formwork.

\section{Factors that Affect the Performance of Fabric Formwork}

Formwork is a part of concrete construction that requires careful planning, both from the selection of material to the selection of the installation method itself. This is done to anticipate the failure of casting due to broken formwork. Therefore, it is necessary to pay attention to the performance of formwork itself. Factors that affect the selection of formwork systems include cost, quality, safety, cycle time, building design, location constraints, available resources, contractor experience, workforce capability, total reputation for capital availability, and methods of implementation (Asadi \& Praneth, 2017). This study will examine more about the costs and time of installing formwork

\section{Installation Time of Formwork}

Project scheduling is the result of planning, which can provide information about the planned schedule and project progress in terms of resource performance in the form of costs, labour, equipment, and materials as well as the project duration plan and the progress of time for project completion. Scheduling is the allocation of time in order to complete a project to achieve optimal results by considering the existing limitations. The preparation of project activities is intended to help carry out project evaluations (Wijayanto, 2014).

\section{Installation Time with Wood Formwork}

The installation of wood formwork does not affect the volume of work. The duration only changes at significant volume differences. In other words, the shape of the structure determines the duration of the installation of wood formwork (Hesna \& Alfalah, 2013). Through the research, Tedja, et al (2015) gets the results of the installation of assistance to $1 \mathrm{~m}^{2}$, as shown in Table 1 .

Table 1. Installation Time of Wood Formwork.

\begin{tabular}{ccc}
\hline No & Job Description & Time (Minute) \\
\hline 1 & Formwork Installation & 44.375 \\
2 & Formwork Dismantling & 7.500 \\
\hline & Total Time & 51.875 \\
\hline
\end{tabular}

2. Installation Time with Brick Formwork

The installation time of brick formwork is influenced by the volume of the structure. At the smaller structure sizes, the installation time will be faster compared to wood formwork. However, if the size is large enough, there is a possibility that the installation time will be longer compared to wood formwork (Hesna \& Alfalah, 2013). Through the research, Tedja, et al (2015) gets the results of the installation of assistance to $1 \mathrm{~m}^{2}$, as seen in Table 2 .

Table 2. Installation Time of Bricks Formwork.

\begin{tabular}{ccc}
\hline No & Job Description & Time (Minute) \\
\hline 1 & Formwork Installation & 7.500 \\
\hline & Total Time & 7.500 \\
\hline
\end{tabular}

\section{Installation Cost of Formwork}

According to Wijayanto (2014), the unit price analysis is the preliminary guideline for calculating the cost of a building plan in which numbers are showing the amount of material, work wages, and the cost per unit of work that will later be needed in planning the budget.

\section{Installation Cost of Wood Formwork}

The analysis of the unit price of $1 \mathrm{~m}^{2}$ formwork installation in IDR for tie beam and pile cap according to SNI 7394-2008 is shown in Table 3 and Table 4.

Table 3. Installation Time of Tie Beam Wood Formwork.

\begin{tabular}{|c|c|c|c|c|c|}
\hline \multicolumn{2}{|c|}{ Installation needs } & Unit & Index & Unit Price (IDR) & Total Cost (IDR) \\
\hline \multirow{3}{*}{ Material } & Wood gradeIII & $\mathrm{m}^{3}$ & 0.040 & 2600000 & 104000 \\
\hline & $5 \mathrm{~cm}-10 \mathrm{~cm}$ nail & $\mathrm{kg}$ & 0.300 & 24600 & 7380 \\
\hline & Formwork oil & $\mathrm{L}$ & 0.100 & 15500 & 1550 \\
\hline \multicolumn{5}{|c|}{ Total cost of material $/ \mathrm{m}^{2}$} & 112930 \\
\hline \multirow{4}{*}{ Labour } & Worker & $\mathrm{OH}$ & 0.520 & 130200 & 67704 \\
\hline & Wood worker & $\mathrm{OH}$ & 0.260 & 149730 & 38930 \\
\hline & Head of worker & $\mathrm{OH}$ & 0.026 & 164052 & 4266 \\
\hline & Foreman & $\mathrm{OH}$ & 0.026 & 174468 & 4537 \\
\hline \multicolumn{5}{|c|}{ Total cost of Labour $/ \mathrm{m}^{2}$} & 115437 \\
\hline \multicolumn{5}{|c|}{ Total cost of Installation $/ \mathrm{m}^{2}$} & 228367 \\
\hline
\end{tabular}


Table 4. Installation Cost of Pile Cap Wood Formwork.

\begin{tabular}{|c|c|c|c|c|c|}
\hline \multicolumn{2}{|c|}{ Installation needs } & \multirow{2}{*}{$\frac{\text { Unit }}{\mathrm{m}^{3}}$} & \multirow{2}{*}{$\begin{array}{r}\text { Index } \\
0.045\end{array}$} & \multirow{2}{*}{$\frac{\text { Unit Price (IDR) }}{2600000}$} & \multirow{2}{*}{$\frac{\text { Total Cost (IDR) }}{117000}$} \\
\hline \multirow{4}{*}{ Material } & Wood gradeIII & & & & \\
\hline & $\begin{array}{c}5 \mathrm{~cm}-10 \mathrm{~cm} \\
\text { nail }\end{array}$ & $\mathrm{kg}$ & 0.300 & 24600 & 7380 \\
\hline & Formrok oil & $\mathrm{L}$ & 0.100 & 15500 & 1550 \\
\hline & \multicolumn{2}{|c|}{ Total cost of material $/ \mathrm{m}^{2}$} & & & 125930 \\
\hline \multirow{4}{*}{ Labour } & Worker & $\mathrm{OH}$ & 0.520 & 130200 & 67704 \\
\hline & Wood worker & $\mathrm{OH}$ & 0.260 & 149730 & 38930 \\
\hline & Head of worker & $\mathrm{OH}$ & 0.026 & 164052 & 4266 \\
\hline & Foreman & $\mathrm{OH}$ & 0.026 & 174468 & 4537 \\
\hline \multicolumn{4}{|c|}{ Total cost of Labour $/ \mathrm{m}^{2}$} & & 115437 \\
\hline \multicolumn{4}{|c|}{ Total cost of Installation $/ \mathrm{m}^{2}$} & & 241367 \\
\hline
\end{tabular}

Table 5. Installation Cost of Brick Formwork.

\begin{tabular}{|c|c|c|c|c|c|}
\hline \multicolumn{2}{|c|}{ Installation needs } & \multirow{2}{*}{$\begin{array}{r}\text { Unit } \\
\text { pcs }\end{array}$} & \multirow{2}{*}{$\begin{array}{c}\text { Index } \\
25\end{array}$} & \multirow{2}{*}{$\frac{\text { Unit Price (IDR) }}{2300}$} & \multirow{2}{*}{$\frac{\text { Total Cost (IDR) }}{57500}$} \\
\hline & Bricks & & & & \\
\hline \multirow[t]{2}{*}{ Material } & Portland Cement & Zak & 0.300 & 53000 & 15900 \\
\hline & Sand & $\mathrm{m}^{3}$ & 0.03 & 185000 & 5550 \\
\hline \multicolumn{5}{|c|}{ Total cost of material $/ \mathrm{m}^{2}$} & 78950 \\
\hline \multirow[t]{2}{*}{ Labour } & Brick worker & $\mathrm{OH}$ & 0.20 & 149730 & 29946 \\
\hline & Head of worker & $\mathrm{OH}$ & 0.020 & 164052 & 3281 \\
\hline \multicolumn{5}{|c|}{ Total cost of Labour $/ \mathrm{m}^{2}$} & 33227 \\
\hline \multirow{4}{*}{ Additional tools } & $\begin{array}{l}\text { Kaso Profil 5/7, } \\
\text { borneo }\end{array}$ & $\mathrm{m}^{3}$ & 0.003 & 3500000 & 10500 \\
\hline & Flax yarn & $\mathrm{m}^{3}$ & 0.065 & 2000 & 130 \\
\hline & Bucket & pcs & 0.025 & 6000 & 150 \\
\hline & Pacul Adk & pcs & 0.015 & 35000 & 525 \\
\hline \multicolumn{5}{|c|}{ Total cost of Additional Tools $/ \mathrm{m}^{2}$} & 11305 \\
\hline \multicolumn{5}{|c|}{ Total cost of installation $/ \mathrm{m}^{2}$} & 123482 \\
\hline
\end{tabular}

\section{Installation Cost of Brick Formwork}

The analysis of the unit price of $1 \mathrm{~m}^{2}$ formwork installation in IDR for tie beam and pile cap according to SNI 7394-2008 can be seen in Table 5.

\section{Method}

This research was conducted by field observation in a project using formwork made from woven polyethylene. The equipment needed is forms for data retrieval, stationery, stopwatch, and camera for the documentation process at the project site. Observation is needed to obtain primary data in research which will be compared with secondary data obtained from the results of literature studies.

The results of measurements of mobilization from the warehouse to the installation area until the installation of spacers on the formwork are needed to the time parameter. For investment cost parameters, it is necessary to have data regarding the calculation of costs both from the material used to the wages of workers per unit area of woven polyethylene formwork.

The field observation has been done in the three different projects. The first project is in the Shop-House Project (Figure 1.). The second project is in the Road Pavement Project (Figure 2.). The last project is Showroom Project (Figure 3.). The observed structural elements are tie beam and pile cap. 


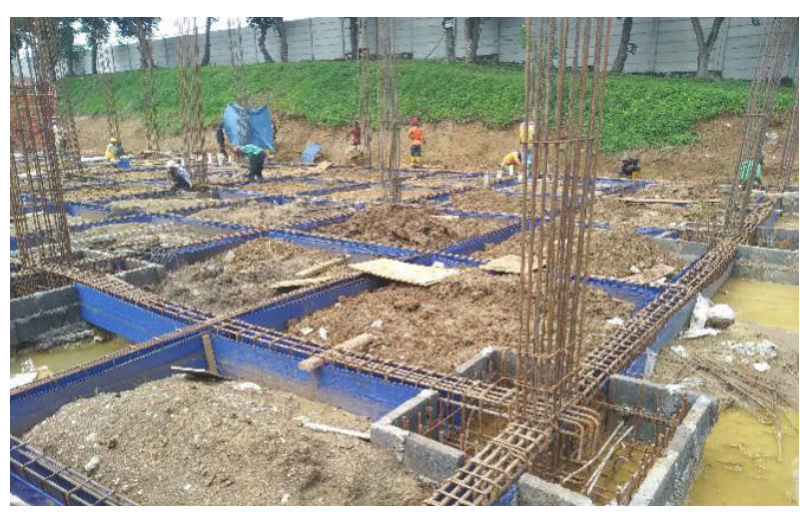

Figure 1. Shop-House Project using woven polyethylene formwork

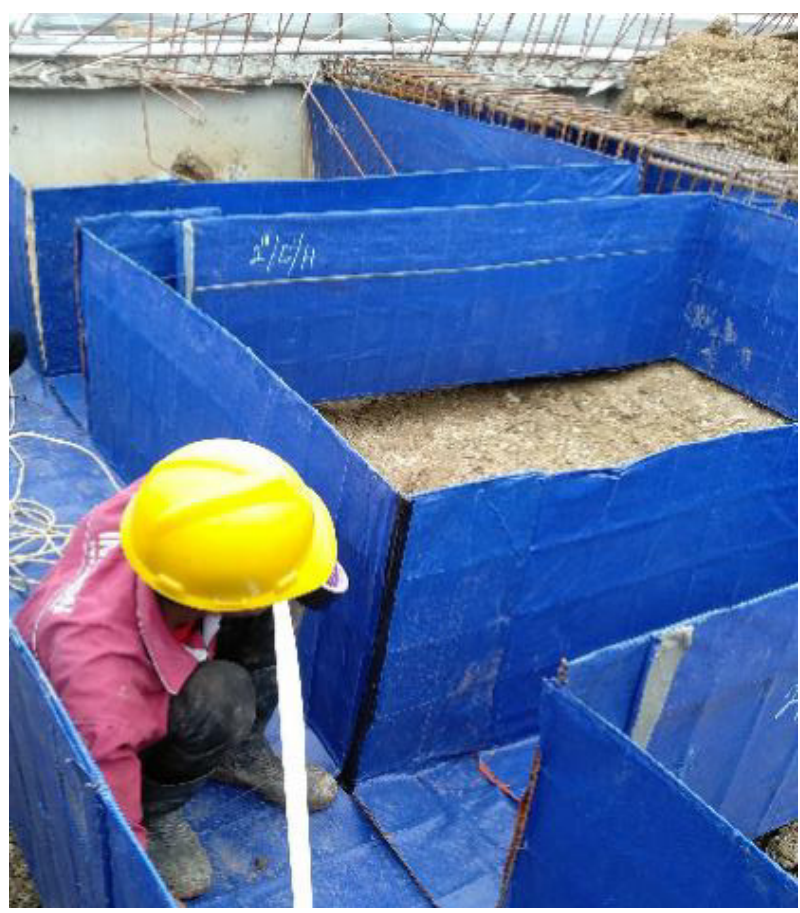

Figure 2. Road Pavement Project using woven polyethylene formwork

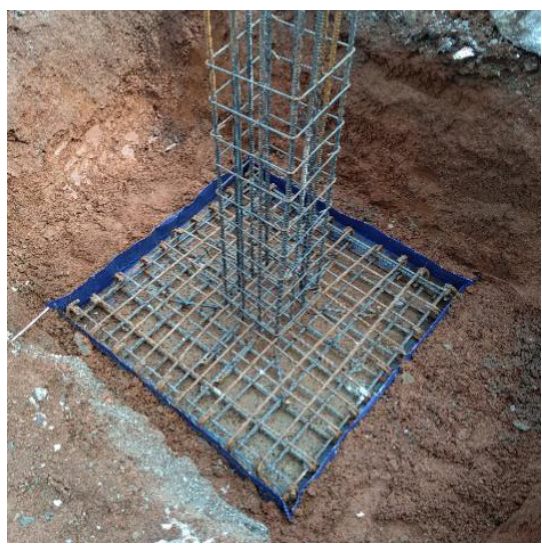

(a)

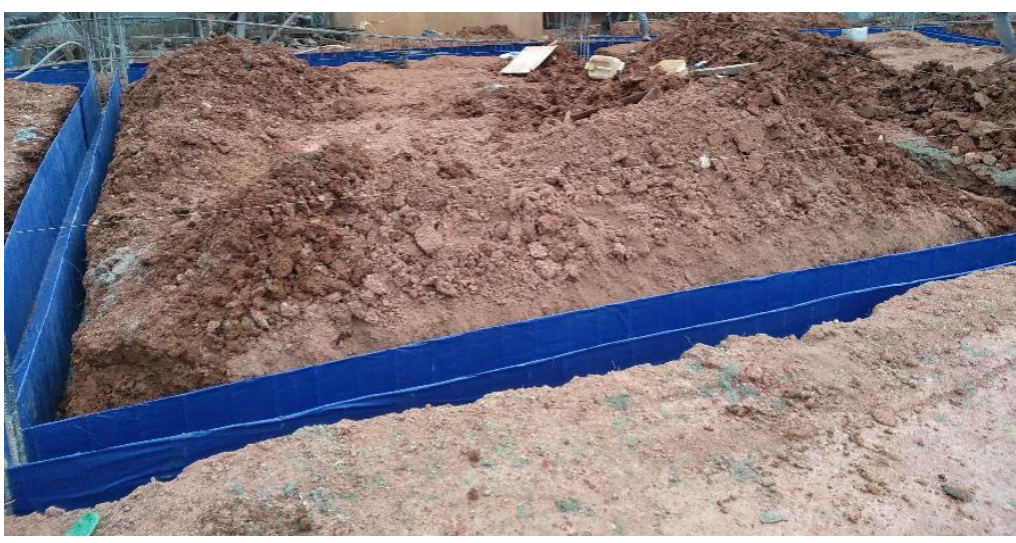

(b)

Figure 3. Showroom Project using woven polyethylene formwork for: (a) pile cap structure, (b) tie beam structure 


\section{Result and Discussion}

\section{Installation Time for Woven Polyethylene Formwork}

Time parameters are measured based on several activities that take place when installing formwork in the related project. The installation activities in the field include the mobilization of formwork from temporary storage areas, the process of cutting formwork (if carried out), the formwork joining process which consists of laying down formwork in accordance with the axles, and linking the wire between the continuous formwork. Thus, the installation time can be defined by the total time needed until the formwork is installed perfectly on a predetermined axle. The following is the formula for the duration used. The duration obtained will be divided by the observed surface area formwork.

\section{Installation Time of Tie Beam Formwork in Shop-House Project}

The area of formwork observed in this project is 249.95 $\mathrm{m}^{2}$, which is 73 observation points observed. The type of structure observed is the tie beam structure. The average installation time for Shop-House Project can be seen in Table 6.

\section{Installation Time of Tie Beam Formwork in Road Pavement}

\section{Project}

The area of formwork observed in this project is 100,64 $\mathrm{m}^{2}$, which is 18 observation points observed. The type of structure observed is the tie beam structure. The average installation time for Road Pavement Project is shown in Table 7.

\section{Installation Time of Tie Beam Formwork in Showroom Project}

The area of formwork observed in this project is $90,9 \mathrm{~m}^{2}$, which is 29 observation points observed. The type of structure observed is the tie beam structure. The average installation time for Road Pavement Project is shown in Table 8 .

It was found that the average installation time for tie beam structure using woven polyethylene formwork was $214.65 \mathrm{~s} / \mathrm{m}^{2}$, which is the shortest time needed for formwork installation compared to other materials such as wood and brick.

\section{Installation Time of Pile Cap Formwork in Showroom Project}

The duration of installation of pile cap structure will be discussed. The observation was done in Showroom Project for 3 observation points. The average installation time for Road Pavement Project can be seen in Table 9.

Table 6. Average Installation time for Shop-House Project using Woven Polyethylene Formwork

\begin{tabular}{|c|c|c|c|c|}
\hline Shop-House & $\begin{array}{l}\text { Mobilization Time } \\
\mathrm{s} / \mathrm{m}^{2}\end{array}$ & $\begin{array}{c}\text { Cutting Time } \\
\mathrm{s} / \mathrm{m}^{2}\end{array}$ & Connection time $s / m^{2}$ & $\begin{array}{c}\text { Installation Time } \\
\mathbf{s} / \mathbf{m}^{2}\end{array}$ \\
\hline Project & 17.83 & 54.62 & 104.95 & 177.40 \\
\hline
\end{tabular}

Table 7. Average Installation time for Road Pavement Project using Woven Polyethylene Formwork

\begin{tabular}{|c|c|c|c|c|}
\hline Road Pavement & Mobilization Time s/m $\mathbf{m}^{2}$ & $\begin{array}{c}\text { Cutting Time } \\
\mathbf{s} / \mathbf{m}^{2}\end{array}$ & Connection Time $\mathbf{s} / \mathrm{m}^{2}$ & $\begin{array}{c}\text { Installation Time } \\
\mathbf{s} / \mathbf{m}^{2}\end{array}$ \\
\hline Project & 24.73 & 27.44 & 182.86 & 235.04 \\
\hline
\end{tabular}

Table 8. Average Installation time for Showroom Project using Woven Polyethylene Formwork

\begin{tabular}{ccccc}
\hline & Mobilization Time & Cutting Time & Connection Time s/m & Installation Time \\
Showroom & $\mathbf{s} / \mathbf{m}^{2}$ & $\mathbf{s} / \mathbf{m}^{2}$ & & $\mathbf{s}^{2} / \mathbf{m}^{2}$ \\
Project & 41.16 & 22.67 & 167.67 & 231.50 \\
\hline
\end{tabular}

Table 9. Total Time of Pile Cap Installation in Showroom Project using Woven Polyethylene Formwork

\begin{tabular}{cccc}
\hline $\begin{array}{c}\text { Observation } \\
\text { Point }\end{array}$ & $\begin{array}{c}\text { Mobilization Time } \\
\mathbf{s} / \mathbf{m}^{\mathbf{2}}\end{array}$ & $\begin{array}{c}\text { Tyding \& Nailing } \\
\mathbf{s} / \mathbf{m}^{\mathbf{2}}\end{array}$ & $\begin{array}{c}\text { Addition of Stir } \\
\mathbf{s} / \mathbf{m}^{\mathbf{2}}\end{array}$ \\
\hline 1 & 130 & 289 & 338 \\
2 & 157 & 310 & 235 \\
3 & 61 & 428 & 440 \\
\hline
\end{tabular}


However, the authors classify the duration again so that it can be compared according to the installation activity in the tie beam structure. Adjustments made including the duration of tidying and nailing the formwork will be combined with the duration of the addition of the mortar on the formwork. In connection with this, there was no cutting in the pile cap structure because the formwork had already been formed. Therefore, the results of this observations can be concluded, as shown in Table 10 .

Table 10. Time of Installation for Pile Cap Structure using Woven Polyethylene Formwork

\begin{tabular}{cccc}
\hline $\begin{array}{c}\text { Area of } \\
\text { Formwork }\end{array}$ & $\begin{array}{c}\text { Mobilization } \\
\text { Time }\end{array}$ & $\begin{array}{c}\text { Tyding, Nailing } \\
\text { \& Addition of }\end{array}$ & $\begin{array}{c}\text { Installation } \\
\text { Time }\end{array}$ \\
1.68 & $\mathrm{~s} / \mathrm{m}^{2}$ & Stir $\mathrm{s} / \mathrm{m}^{2}$ & $\mathrm{~s} / \mathrm{m}^{2}$ \\
1.68 & 77.38 & 373.21 & 450.60 \\
1.68 & 93.45 & 324.40 & 417.86 \\
\hline
\end{tabular}

The comparison of time of installation of formwork for tie beam and pile cap structures is shown in Table 11 .

Table 11. The Average of Time Installation for Tie Beam and Pile Cap Structure using Woven Polyethylene Formwork

\begin{tabular}{ccc}
\hline Type of & Installation Time & $\begin{array}{c}\text { Average Installation } \\
\text { Sime } \\
\text { Structure }\end{array}$ \\
Tie Beam & 214.65 & $\begin{array}{c}\mathrm{s}^{2} \\
\mathrm{~s}\end{array}$ \\
Pile Cap & 473.81 & 344.23 \\
\hline
\end{tabular}

From the table, it can be concluded that the installation time for pile cap structure is 2.2 times longer than for tie beam structure. That is because there are additional activities needed for the pile cap installation process, namely the process of tidying and nailing, and the addition of stir. In addition, the pile cap is at an elevation of $-1.5 \mathrm{~m}$, therefore the formwork material mobilization process takes longer than the mobilization process in the tie beam structure.

From the results above, it was found that the average installation time for woven polyethylene formwork was $344.23 \mathrm{~s} / \mathrm{m}^{2}$. When compared with other materials, the installation time using woven polyethylene formwork is 500 times faster than using wood material and 80 faster than using brick material.

\section{Installation Cost for Woven Polyethylene Formwork}

The cost required to make $1 \mathrm{~m}^{2}$ formwork made from woven polyethylene is IDR 75000 . These costs include material and labour costs.

From the unit price analysis table for tie beam and pile cap, the total installation price $/ \mathrm{m}^{2}$ is IDR 125000 with brick material and IDR 240000 with wood material. From the data obtained, it can be concluded that the total installation cost for woven polyethylene formwork is IDR $75,000 / \mathrm{m}^{2}$ which is 1.7 times cheaper than using brick material and 3.2 times cheaper than using wood material.

\section{Conclusion}

Based on the results of the research, in terms of time, woven polyethylene formwork has a faster installation time compared to other materials such as woods and bricks, which has an average installation time of $344.23 \mathrm{~s} / \mathrm{m}^{2}$. In terms of cost, woven polyethylene formwork is cheaper compared to other materials such as wood and brick, which has an installation cost of IDR $75000 / \mathrm{m}^{2}$. It can be concluded that in its installation, the use of formwork made from woven polyethylene is quite effective as a substitute for conventional materials such as wood and brick. But for woven polyethylene formwork, it is possible to have the additional costs for spacers if the height of the formwork is more than $60 \mathrm{~cm}$.

Table 12. Installation Cost of Woven Polyethylene Formwork

\begin{tabular}{|c|c|c|c|c|c|}
\hline \multicolumn{2}{|c|}{ Installation needs } & Unit & Index & Unit Price (IDR) & Total Cost (IDR) \\
\hline \multirow{2}{*}{ Material } & $\begin{array}{c}\text { Woven } \\
\text { polyethylene }\end{array}$ & $\mathrm{m}^{2}$ & 1 & 45000 & 45000 \\
\hline & Wire mesh $\mathrm{m} 4$ & zak & 1 & 13977 & 13977 \\
\hline \multicolumn{4}{|c|}{ Total cost of material $/ \mathrm{m}^{2}$} & & 58977 \\
\hline \multirow[t]{2}{*}{ Labour } & Worker & $\mathrm{OH}$ & 0.3 & 34750 & 10425 \\
\hline & Foreman & $\mathrm{OH}$ & 0.133 & 47140 & 6269 \\
\hline \multicolumn{5}{|c|}{ Total cost of Labour $/ \mathrm{m}^{2}$} & 16694 \\
\hline \multicolumn{5}{|c|}{ Total cost of Installation $/ \mathrm{m}^{2}$} & 75671 \\
\hline
\end{tabular}




\section{Acknowledgement}

This research is funded and supported by DRPM Universitas Indonesia through Indexed International Publication Grant for Student Final Project (Hibah Pitta 2019). The number of Contract is: 0743/UN2.R3.1/HKP.05.00/2019.

\section{REFERENCES}

[1] Asadi, S., \& Praneth, P. (2017). A Comparative Study for Evaluation of Different Formwork Systems Utilization in Construction Projects. International Journal of Mechanical Engineering and Technology (IJMET), 21-29.

[2] Chandler, A. (2015). Fabric Formwork - Prototype to Typology. The Journal of Architecture, 20(3), 420-429.

[3] Chang, H. C. (2007). Productivity Analysis of Construction Formwork in Residential Building, MS Thesis. Department of Civil engineering, National Taiwan University, Taiwan (in Chinese).

[4] Hanna, A. S. (1999). Concrete formwork systems. New York: Marcel Dekker, Inc.

[5] Hawkins, W.J., Herrmann, H., Ibell, T.J., Kromoser, B., Michaelski, A., Orr, J. J., Pedreschi, A., Pronk, A., Schipper, R., Shepherd, P., Veenendaal, R., Wansdronk, R. and West, M. (2016). Flexible Formwork Technologies: A State of the Art Review. Structural Concrete, 17, 6. https://doi.org/10.1002/suco.201600117

[6] Hesna, Y., \& Alfalah, R. (2013). Variasi Penggunaan Jenis Material Bekisting Pada Pekerjaan Struktur Pile Cap dan Pengaruhnya Terhadap Biaya dan Durasi Pelaksanaan Proyek. KoNTeks 7, 197-203.

[7] Hurd, M. K., (1995). Formwork for Concrete.

[8] Jones, Ed. (2003). Estimating cost for wood formwork fabricated onsite. Concrete Construction-World of Concrete, 48(4), 54-55.

[9] Lamberton, B. (1989). Fabric forms for concrete. Conc. int, 58-67.

[10] NOrr, J. J., Darby, A. P., Ibell, T., \& Evernden, M. C. (2011). Concrete Structures Using Fabric Formwork. The Strustural Engineer, 20-16.

[11] Seracino, D., Rudi, Cauberg, N., Tysmand, T., Adriaenssens, S., Wastiels, J., Mollaert, M., Belkassem, B. (2012). Shell
Elements of Textile Reinforced Concrete using Fabric Formwork: a Case Study. Advances in Structural Engineering, 15(4), 677-690.

[12] SNI 7394:2008. (2008). The procedure for calculating the unit price of concrete work for construction of buildings and housing. Badan Standarisasi Nasional.

[13] Sutherland, M. (2005). Formwork Economics, Concrete Engineering International, 9(4), 18-19.

[14] Orr, J.J., Darby, A., Ibell, T. J., Evernden, M.C., Otlet, M. Concrete Structures using Fabric Formwork. Structural Engineer, 89(8), 20-26.

[15] Pedreschi, R. \& Lee, D. S. H. (2014). Structure, Form and Construction. Fabric Formwork for Concrete. In Proceedings of Across: Architectural Research through to Practice. $48^{\text {th }}$ International Conference of the Architectural Science Association.

[16] Tedja, M., Halim, H., Divaninta, K., \& Hidayat, V. (2015). Comparison Formwork Wood Sloof to Batako Viewed from the Aspect of Time and Cost. ComTech, 499-504.

[17] Umit Dikmen, S. \& Sonmez, M. (2011). An artificial neural networks model for the estimation of formwork labour. Journal of Civil Engineering and Management, 17(3), 340-347. http://dx.doi.org/10.3846/13923730.2011.594154.

[18] Van Mele, T. \& Block, P. (2011). A Novel Form Finding Method for Fabric Formwork for Concrete Shells. J. Int. Assoc. Shell and Spatial Structures, 52, 217-224.

[19] Veenendaal, D. \& Block, P. (2012). Computational Form Finding for Fabric Forworks: An Overview and Discussion. In Proceedings of the $2^{\text {nd }}$ International Conference on Flexible Formwork, J. et al. Ohr (ed.) Bath, UK, 368-378.

[20] Veenendaal, D. \& Block, P. (2014). Design Process Prototype Concrete Shells using a Hybrid Cable Net and Fabric Formwork. Engineering Structures, 75, 39-50.

[21] West, M. (1994). Fabric Formwork. Progressive Architechture, 88.

[22] West, M \& Araya. (2012). R. Recent Fabric Formwork Construction Projects. In Proceedings of the Second International Conference on Flexible Formwork, University of Bath, UK.

[23] West, M. (2016). The Fabric Formwork Book: Methods for Building New Architectural and Structural Forms in Concrete. Routledge.

[24] Wijayanto, B. R. (2014). Metode Pelaksanaan dan Analisa Biaya Bekisting pada Pekerjaan Struktur. Jurnal Karya Teknik Sipil, 773-784. 